Original Research Paper

\title{
Government Expenditure and School Efficiency and Productivity Change: A Case of Public Primary Schools in Kenya
}

\author{
Mutinda Mutuku, Julius Korir and Dianah Ngui-Muchai \\ School of Economics, Kenyatta University, Kenya
}

\author{
Article history \\ Received: 28-11-2018 \\ Revised: 01-03-2019 \\ Accepted: 16-04-2019 \\ Corresponding Author: \\ Mutinda Mutuku \\ School of Economics, Kenyatta \\ University, Kenya \\ Email: mutukus2002@yahoo.co.uk
}

\begin{abstract}
Education management is a more labor intensive process previously measured by level of school enrolment and education quality with low or no concern on productivity and efficient resource utilization. Trends in increasing government allocation to education sector demonstrate a positive impact on enrolment, education quality and efficiency levels determined in the study. However, there was a gap on how government expenditures impacted school technical efficiency in public primary schools. To determine schools' technical efficiency and relative determinants; this study used data from the Southern and Eastern Africa Consortium for Monitoring Educational Quality (SACMEQ) data which evaluated class six performance for 3 times periods (2000, 2004, 2012). In the analysis, Data Envelopment Analysis (DEA) and Two Stage Least Squares are applied. Results revealed that technical efficiency scores in 8 provinces were lower in 2004 compared to 1997 but increased in 2007 with productivity change exhibiting same trends. Input change for enrolment and school amenities affected overall output. Class-pupil and pupil-toilet ratio, distance from small town, dispensary, bookshop and secondary school as well as class type contributed negatively to efficiency scores. Class-book ratio, government expenditure, playfield availability and class numbers contributed positively to efficiency. The results showed that schools located near main road and library had positive relationship to level of efficiency. On policy, expenditures should be increased towards quality classes and more qualified teachers who are high determinants efficiency.
\end{abstract}

Keywords: School Performance, Efficiency, Productivity, Government Expenditure

\section{Introduction}

Background

The principal measure of school performance in Kenya has primarily been the amounts allocated to the primary education sector and the qualification pupils achieve in the Kenya Certificate of Primary Education Examinations (KCPE). In most cases, education management is more labour intensive, hence productivity and efficiency utilization of available resources including human resource, school infrastructures should be considered as a key indicator of school performance (Fishlow, 1995; Odusola, 1998; Persson and Tabellins, 1994; Muyanga et al., 2010). In the seminal work on human capital development by Becker, Mincer and Schultz in the 1960 's, there has been increased interest on investment in the education sector with respect to technical efficiency which should be considered in primary level of education (Lucas, 1988; Mincer, 1974).

Although existing studies have established existence of an effect of government expenditure on enrolment and quality of education, very little have been undertaken on school efficiency levels as an indicator of quality of education (Aghion and Howitt, 1988; Alesina and Rodrik, 1994; Benhabib and Spiengel, 1994; Lucas, 1988; Romer, 1990; Nelson and Phelps, 1966; Bowers and Urick, 2011). This study seeks to answer a critical question on how expenditures by the government affect school technical efficiency. 
The question at hand explains a prescribed hypothesis that measurement of school performance by increase in human capital inherent in labour productivity leads to productivity that is triggered towards output equilibrium levels to enhance enrolment levels, quality of education and efficiency levels. The hypothesis is as a results of neoclassical growth theory discussions (Mankiw et al., 1992; Bold et al., 2011; Mazar et al., 2007; Cohen and Dupas, 2010).

\section{Trends in Financing Public Primary Education in Kenya}

Marginally, the increasing enrolment across the years demonstrated a level of investment in an economy that affected almost all sectors which signaled a positive growth in education expenditures accounting for only $1.1 \%$ of GDP (Republic of Kenya, 2005). The explained trend in financing are demonstrated in Fig. 1.

The positive changes in school enrolments may translate to high levels of inefficiency on the utilization of resources if not checked. The resultant outcome would be low enrolment, high drop outs, grade repetition, low completion and poor transition rates (Bedi et al., 2002; Kimalu et al., 2001; Bold et al., 2011; Nyamoita, 2013; Lee et al., 2005).

\section{Technical Efficiency in Primary Schools}

Technical efficiency analysis evaluates how well resources are utilised in a school (Hanushek and Woessman, 2008). It also explains the use of productive resources in the most optimal technology and efficient way resulting to the highest possible output from a combination of a set of inputs. In a school setting production inputs including household's socio-economic levels, school type, school size, geographical index and pupil-teacher ratio (Charnes and Cooper, 1985; Koopmans, 2013; Kwabena and Appiah, 2004; Mizala and Rumaguera, 2000; Nyamoita 2013; Mizalla and Rumaguera, 2000; Worthington, 2001).

\section{Data Sources and Analysis}

Secondary data used in the study was collected from the United Nations Education, Scientific and Cultural Organization (UNESCO) - the Southern and Eastern Africa Consortium for Monitoring Educational Quality (SACMEQ) I, II and III for the years 2000, 2004 and 2012 and Statistical Abstracts for the year 1996/7 to 2014/15 using school based cross-section survey approach for class 6 pupils and covered the 8 regions in Kenya. The study also covered several characteristics including pupil characteristics, school-based characteristics as well as teacher and households' characteristics respectively. Data on government expenditure and respective enrolment for the years was collected from different statistical abstracts covering the period around 2000 before the introduction of Free Primary Education (FPE), 2004 representing one year after the introduction of FPE and 2012 representing a rather stable period after the implementation of FPE programme. Relevant variables specific to the study were extracted from the data set, coded and applied in analysis non-parametric measure for technical efficiency measurement using Data Envelopment Analysis Programme (DEAP) model. Causes of inefficiency were determined through a second stage analysis by applying censored Tobit regression model using STATA

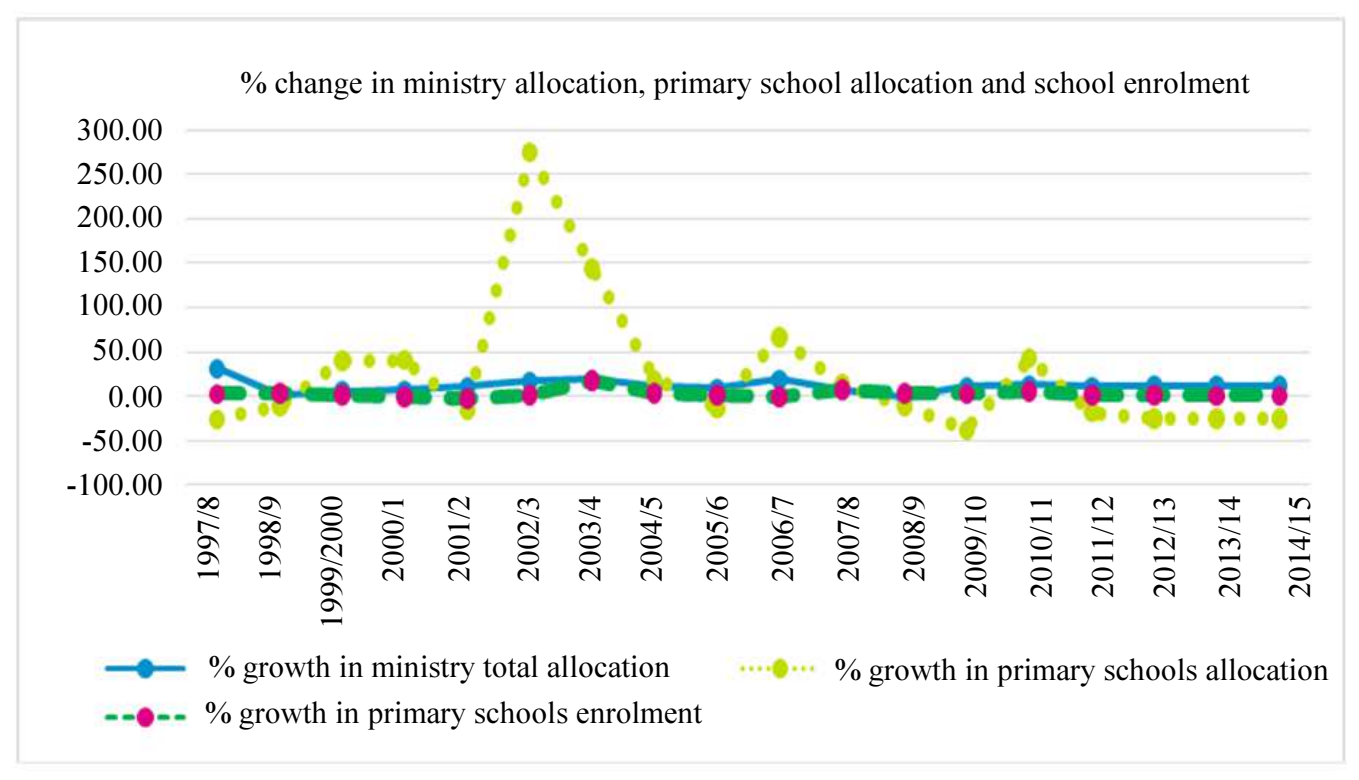

Fig. 1: Percentage Growth in Ministry of Education Allocation, Primary Education Allocation and School Enrolment, Source: Republic of Kenya, 1998-2007 


\section{Reviewed Literature}

\section{Theory of Production and Primary Education}

\section{Empirical Literature on Theory of Production}

Studies on technical efficiency use either DEA or Stochastic Frontier Analysis for efficiency measurement. The studies adopted various inputs among them teacherpupil ratio, pupil gender, school expenditures, household characteristics and partly school characteristics. In addition, school outputs used in the studies comprised of subject scores attained during impact evaluation. The output was found in all studies except for Abagi and Odipo (1997) who used school completion levels. A limitation in the studies found that, final year test scores used were biased because evaluation was done at a time when pupils were conditioned to take an examination which in most instances provided the biased scores. The analysis used in the studies to achieve these results included Stochastic Frontier Analysis (SFA) which included censored regression model and DEA approach.

SFA model was often not used in most of the studies as it worked well with a few inputs and outputs thus DEA model is applied due to its capacity to convert inputs and outputs into a single measure of efficiency. The measure of efficiency would be for each decision making unit comprising of multiple inputs and outputs without requirement for homogeneous measurements (Kanina, 2013; Kwabena and Appiah, 2004; Mizala and Miguel, 2007; Nyamoita, 2013; Kirigia et al., 2000). In all the studies reviewed, only one Kanina (2013) used TSLS to establish determinants of efficiency. Learning from the reviewed literature, this study adopted DEA model for analysis of technical efficiency measurement. The results provided comprehensive results for technical efficiency change, technological change and scale efficiency. In this study, censored Tobit model for TSLS analysis is used to establish the determinants of efficiency.

\section{Mathematics Literature on Theory of production}

Production function in a school setting provides a means of understanding overall process by estimating effects of given inputs that are used to achieve the expected school performance incorporating input factors and expected outputs. The model adopts cobb-douglas output function that applies translog framework for a school output with $k$ inputs is presented as:

$$
\ln y=\alpha+\sum_{k=1}^{k} \beta_{k} \ln x_{k}+\frac{1}{2} \sum_{k=1}^{k} \sum_{m=1}^{k} \gamma_{k m} \ln x_{m}
$$

Equation 2.1 provides a translog multiple output cost for $k$ inputs to $l$ outputs. Further, the equation provides the analysis of translog model as:

$$
\begin{aligned}
& \ln C=\alpha+\sum_{k=1}^{k} \beta_{k} \ln w_{k} \\
& +\frac{1}{2} \sum_{k=1}^{k} \sum_{m=1}^{k} \gamma_{k m} \ln w_{k} \ln w_{m}+\sum_{s=1}^{L} \delta_{s} \ln y_{s} \\
& +\frac{1}{2} \sum_{s=1}^{L} \sum_{t=1}^{L} \varphi_{s t} \ln y_{s} \ln y_{t}+\sum_{k=1}^{K} \sum_{s=1}^{L} \theta_{k s} \ln w_{s} \ln y_{s t}
\end{aligned}
$$

Equation 2 relaxes restrictions on demand elasticities and elasticities of substitution with the translog translating the function to a monotonic condition expressed as (Salvanes and Tjotta, 1998):

$$
s_{k}=\frac{\partial \ln c}{\partial \ln w_{k}}=\beta_{k}+\sum_{m \gamma k m} \ln w_{m} \geq 0, k=1
$$

where, $k=1$ are non-negative factor shares

The concavity condition of the model is also given as:

$$
\Gamma=[\gamma \mathrm{km}], S=\operatorname{diag}\left[s_{k}\right] \text { and } s=\left[s_{1}, s_{2, \ldots} s_{k}\right]^{T}
$$

When technical efficiency is integrated in the inputoutput model, production is therefore defined as the process of transformation of a set of inputs denoted by $x \in \Delta_{k}^{+}$in to a set of outputs $y \in \Omega_{M}^{+}$. The production transformation process presented as $T(y, x)=0$ where 0 normalises the natural view, where an input requirement set is expressed as:

$$
L(y)=\{x:(y, x) \text { isproducable }\}
$$

where, $L(y)$ is the vector of output $y$.

Efficiency is thus explained in the production model defined by the isoquant:

$$
I(y)=\{x: x \in L(y) \text { and } \lambda x \notin L(y) \text { if } 0 \leq \lambda<1\}
$$

whose boundary on the input requirement set is set as:

$$
\begin{aligned}
& E S(y)=\{x: x \in L(y)\} \text { and }\left\{x^{\prime} \notin L(y)\right\} \\
& \text { for }\left\{x^{\prime}\right\} \text { when }\left\{x_{k}^{\prime} \leq x_{k} \forall k\right\} \text { and }\left\{x_{k}^{\prime}<x_{j} \text { forsome }\right\}
\end{aligned}
$$

The equation 2.10 is presented in Fig. 2.

The Fig. 2 shows that $X^{A}=\left(x_{1}^{A}, x_{2}^{A}\right)$ is on the isoquant, but it is not the efficient subset. This is because there is a slack in $x_{2}^{A} . X^{B}$ which has both $I(y)$ and $E S(y)$. The distinction between these two sets are applicable in the Data Envelopment Analysis (DEA model). According to Farrell (1957) the measure of efficiency may not be equated to 1 if some levels of inefficiency are exhibited and $T E(y, x) \neq 1$. In this case, $T E$ would be $\theta$ and thus $0 \leq \theta \leq 1$ therefore the level of inefficiency is $1-\theta$ as presented in Fig. 3. 


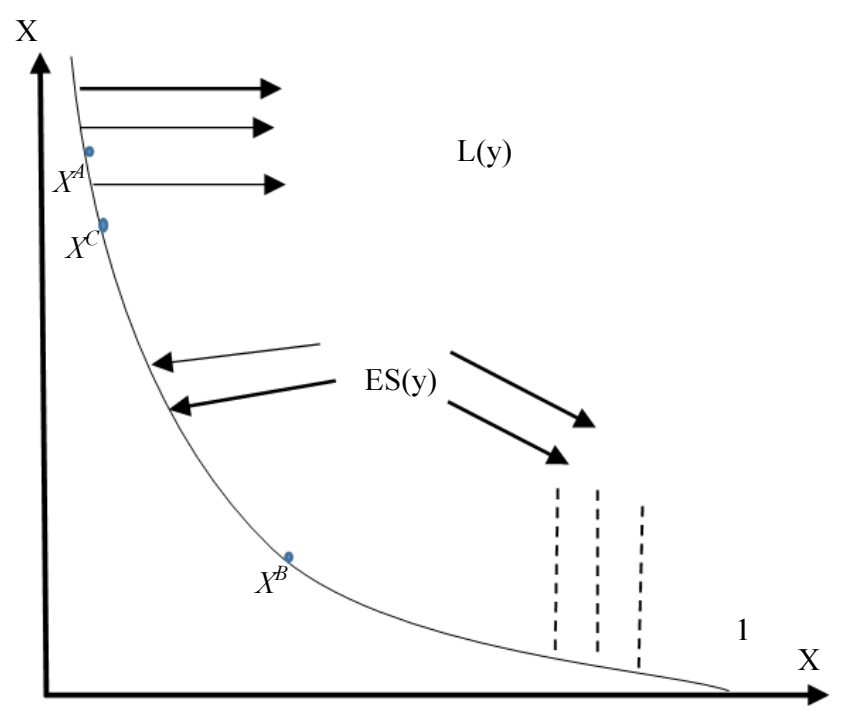

Fig. 2: Technical Efficiency Input requirement

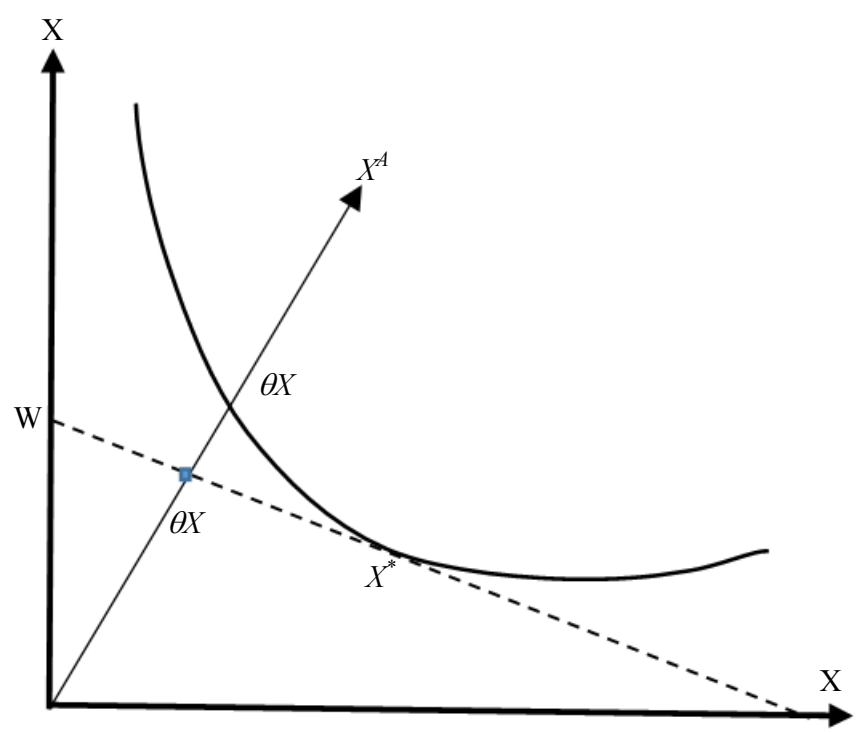

Fig. 3: Technical and Allocative Inefficiency

The Debreu-Farrell production model outlined in Fig. 3 is expressed as:

$y_{i}=f\left(x_{i}, \beta\right) T E_{i}$

Where:

$$
0<T E\left(y_{i}, x_{i}\right) \leq 1
$$

In the equation, $\beta$ is the vector of parameter in the production vector of parameters estimated. The production model discussed is linear in logs of the variables expressed as:

$\ln y=\ln f\left(x_{i}, \beta\right)+\ln T E_{i}=\ln f\left(x_{i}, \beta\right)-\mu_{i}$

where, $\mu_{I} \geq 0$ is a measure of technical inefficiency.

The assumption outlined holds given that:

$\mu_{i}=-\ln T E \approx 1-T E_{i}$, thus $T E_{i}=\exp \left(-\mu_{i}\right)$

A study by Sherperds (1953) outlines that input distance function expressed as: 


$$
D_{I}(y, x)=\max \left\{\lambda:\left[\frac{1}{\lambda}\right] X \in L(y)\right\} \text { and } D_{I}(y, x) \geq 1
$$

is presented on the isoquant set of $x s$ where:

$$
D_{I}(y, x)=1
$$

Further analysis by Debreu (1951) and Farrell (1957) found that input-oriented technical efficiency given as:

$$
\operatorname{TE}(y, x)=\min \{\theta: \theta x \in L(y)\}
$$

The equation 2.12 is solved as:

$$
T E(y, x) \leq 1
$$

and therefore technical efficiency is defined as:

$$
T E(y, x)=\frac{1}{D_{I}(y, x)}
$$

In a school environment, the adopted theory of production applies various technical efficiency measurements (Abagi and Odipo, 1997; Afonso and Aubyn, 2006; Charnes et al., 1978; Charnes and Cooper, 1985; Grosskopf et al., 1997; Muvawala and Hisali, 2012; Nyamoita, 2013). This includes the modern efficiency measurement that begins with Farrell's (1957) work, who drew upon the work of Debreu (1951) and Koopmans (1951). Further, Lovell (1993) notes that technical efficiency in a school setting is given as the ratio of outputs to the number of inputs utilised as presented in Fig. 4.

The Fig. 4 presents Farrell's theory of the production frontier which involves original input and output values. The horizontal axis denotes the amounts of inputs, $\mathrm{X}$, utilised to produce output, $Y$. When inputoutput values are utilised, on the production frontier $(\pi)$, then schools do not attain the maximum possible output. As indicated in Point A, the technical efficiency of a given school producing output, $y$, from inputs $X$ can be calculated as $\frac{y}{y^{\prime \prime}}$ where $y^{\prime \prime}$ is the quality of output $B$ on the production frontier.

\section{DEA Model of Estimating Efficiency}

Non-parametric approaches use linear programming approaches and frequently apply Data Envelopment Analysis (DEA) for analysis which is superior to Ratio Analysis, Stochastic Frontier Measurement and Regression Analysis). The DEA strength include: (1) Ability to convert inputs and outputs into a single measure of efficiency for each school, (2) DEA handles multiple inputs and outputs without requirement for homogeneous measurements, (3) DEA can adjust for exogenous variables that are outside control of firms management, (4) DEA does not require specific functional form relating inputs to outputs, so as to compute the efficiency of a school and (5) DEA focuses on observed best practice frontier unlike stochastic frontier models which focuses on central tendency properties (Bowlin, 1996; Burgess, 1998; Charnes et al., 1978; Coelli, 1996).

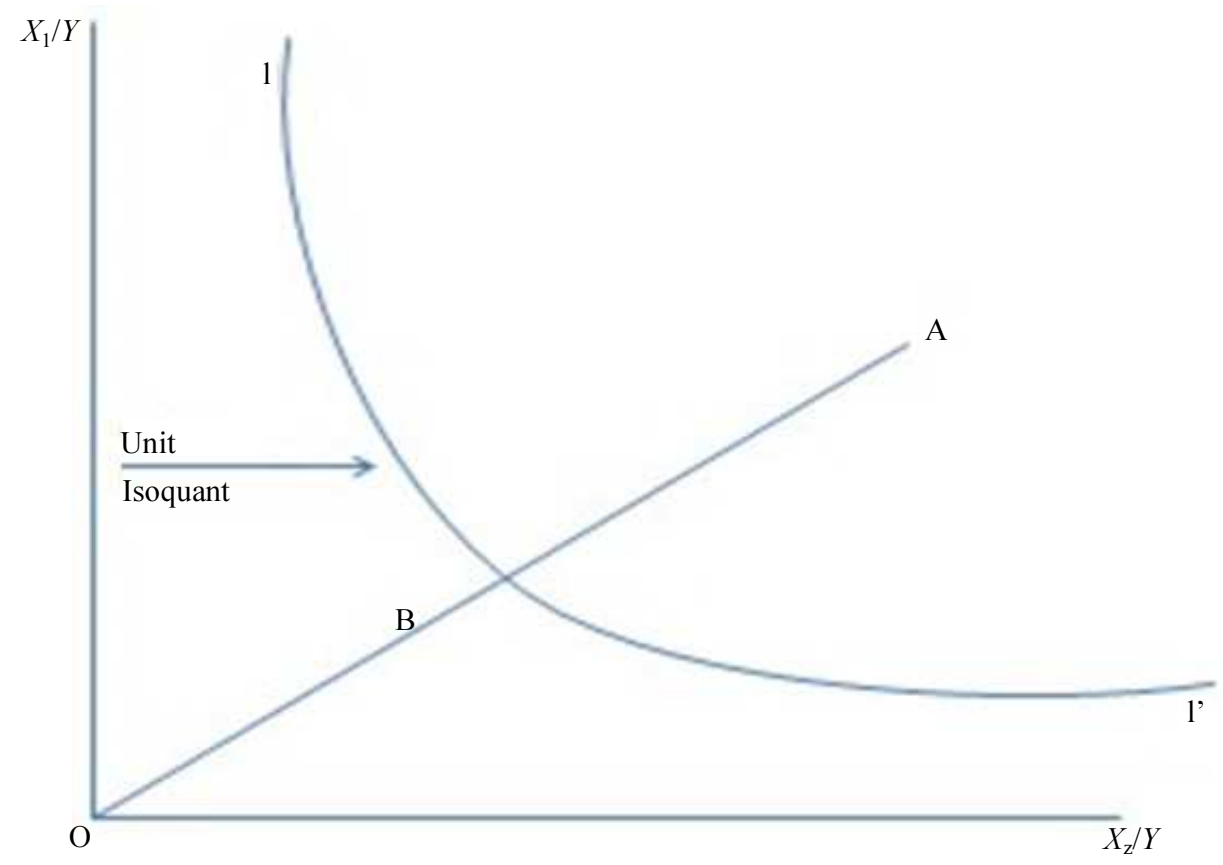

Fig. 4: Technical Efficiency and the production frontier 


\section{Methodology}

\section{Production Theory and Government Expenditure}

The education production function discuss school operations in skill development from a cobb-Douglas model form expressed as:

$$
Q=A E^{\alpha} R^{\beta} \forall \alpha+\beta \leq 1
$$

where, $Q$ are the inputs to school score depended on school characteristics; $(A)$ are school characteristics; $(E)$ student characteristics and $(R)$ government expenditure with parameters $\alpha, \beta$ being elasticities.

Given its pioneer framework, the model therefore formed a basis of productivity model, adoption of either a deterministic, stochastic or panel data model, the equation adopts output $(Y)$ and product of a known function of a vector $X$, which is defined by Aigner and Chu (1968; Lovell and Schmidt, 1977; Pitt and Lee, 1981) as:

$$
Y_{i}=f\left(x_{i}: \beta\right) \exp \left(-\mu_{i}\right), i=1,2, \ldots N
$$

Where:

$Y_{i}=$ The possible production level for $i$ th sample function.

$f\left(x_{i}: \beta\right)=$ A suitable function of the vector

$x_{i}=$ The number of inputs for $i$ th school/firm and of unknown parameters

$\mu_{I} \quad=$ The non -negative random variable with school specific functions which contribute to the $i$ th school not attaining maximum efficiency of production.

$N \quad=$ Represent the number of schools involved in a cross-sectional summary of the education sector

$Y_{i} \quad=$ Bounded above by the deterministic quantity $f\left(x_{i}: \beta\right)$ hence Equation 3.2 is deterministic production function with inequality relationship given as:

$Y_{i} \leq f\left(x_{i}: \beta\right), i=1,2, \ldots N$

From the production model in equation 3.39, technical efficiency expressed from the deterministic function model in equation 3.38, using output in the $i^{\text {th }}$ school is given as:

$$
Y_{i}^{*}=f\left(x_{i}: \beta\right)
$$

and thus technical efficiency is expressed as:

$$
\begin{aligned}
& T E_{i}=\frac{Y_{i}}{Y_{i}^{*}} \\
& =f\left(x_{i}: \beta\right) \exp \frac{\left(-\mu_{i}\right)}{f\left(x_{i}: \beta\right)} \\
& =\exp \left(-\mu_{i}\right)
\end{aligned}
$$

\section{DEA Model for Technical Efficiency Measurement}

In the model definition, consider $n$ schools and each uses $m$ inputs such that $x_{i j}(i=1, \ldots, m)$ to produce $s$ outputs $y_{r j}(r=1, \ldots, s)$ assuming that all inputs and outputs are non-negative in a Production Possibility Set (PPS). Under the Constant Returns to Scale (CRS) assumption, the PPS is derived as:

$$
P_{c}=\left\{(x, y) \mid x \geq \sum_{j=1}^{n} \lambda_{j} x_{j}, y \leq \sum_{j=1}^{n} \lambda_{j} y_{j}, \lambda_{j} \geq 0, j=1, \ldots, n\right\}
$$

where, $x_{j}$ and $y_{j}$ are the input vectors and output vector of

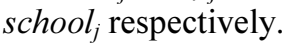

Adopting the Charnes et al. (1978) CCR model, the radial proportional change of inputs or outputs is indicated as:

$$
\begin{aligned}
& \theta^{*}=\min \theta \\
& \text { s.t } \sum_{j=1}^{n} \lambda_{j} x_{i j} \leq \theta x_{i k}, i=1, \ldots, m, \\
& \sum_{j=1}^{n} \lambda_{j} y_{i j} \geq x_{i k}, i=1, \ldots, s, \\
& \lambda_{j} \geq 0, j=1, \ldots, n, \theta \text { free }
\end{aligned}
$$

where, the optimal solution of $\theta^{*}$ is efficiency score. In this paper, a school was said to be efficient if $\theta^{*}=1$ and inefficient if $\theta^{*}<1$.

Further, let $X$ be a $m^{*} k$ matrix of inputs that are constructed from a vector of inputs, $x_{i}$, in $k$ schools. Thus $Y$ denote a $n^{*} k$ matrix of outputs, $y_{i}$, of the $k$ schools. The output-oriented Variable Returns to Scale (VRS) frontier is thus expressed as:

$$
\begin{aligned}
& \operatorname{Min} \theta \\
& \theta, \lambda \\
& \text { Subject to }-y_{i} / \theta-Y \lambda \geq 0 \\
& x_{i}-X \lambda \geq 0 \mathrm{kI} \lambda=1 \lambda \geq 0
\end{aligned}
$$

where, $k 1$ is a $N^{*} 1$ vector of $1 s, \lambda$ is and a $k^{*} 1$ vector of weights while $\theta$ is the output distance measure which is between 0 and 1 . In this respect, $1 / \theta$ are the levels of efficiency scores by which output of $i^{\text {th }}$ school could be expanded while keeping input quantities constant (Coelli, 1996). The variables for efficiency determination are outlined in Annex Table 1.

\section{Determinants of Inefficiency}

The empirical censored Tobit model that was used to establish determinants of efficiency in equation 3.8 was adopted from Breusch et al. (1989; Cameron and Trivedi, 2010; Woodridge, 2002); taking the form:

$y=\left\{\begin{array}{l}1 \\ 0\end{array}\right.$ if $y>0$ 
where, $y$ is the inefficiency score that had been achieved from equation 3.9.

By introducing a latent variable $y_{i}^{*}$ then:

$$
\begin{aligned}
& E\left(y_{i}^{*} \mid x\right)=x_{i}^{\prime} \beta \\
& y_{i}^{*}=x_{i}^{\prime} \beta+\varepsilon_{i} \\
& \varepsilon_{i} \approx \text { i.i.d.N }\left(0, \sigma^{2}\right) \\
& y_{i}= \begin{cases}y_{i}^{*} & \begin{array}{l}
y_{i}^{*}>0 \\
0
\end{array} \\
y_{i}^{*} \leq 0\end{cases} \\
& \text { and } \left.\left\{x_{i}, y_{i}\right): i=1,2,3\right\}
\end{aligned}
$$

where, $x_{i}$ are the various variables used to determine the levels of efficiency levels in the model.

The censored observation then became:

$$
\begin{aligned}
& \operatorname{pr}\left(y_{i}=0\right)=\operatorname{pr}\left(y_{i}^{*} \leq 0\right) \\
& =\operatorname{pr}\left(\varepsilon_{i} \leq-x_{i}^{\prime} \beta\right)=\operatorname{pr}\left(\frac{\varepsilon_{i}}{\sigma} \leq-\frac{x_{i}^{\prime} \beta}{\sigma}\right) \\
& =\varphi\left(-\frac{x_{i}^{\prime} \beta}{\sigma}\right)=1-\varphi\left(\frac{x_{i}^{\prime} \beta}{\sigma}\right)
\end{aligned}
$$

The variables used to determine the determinates of inefficiency are presented in Annex Table 2.

\section{Findings}

\section{Summary Statistics}

The summary statistics adopted school as the unit of analysis which were sampled across based on the predevolution administration locations as shown in Table 1.

Table 1 shows the number of schools sampled for the study were 174, 173 and 181 for years 2000, 2004 and 2012 respectively. The Table 2 represents the mean and standard deviations for government expenditures in the eight provinces for the period 2000, 2004 and 2012.

Table 2, shows the mean amount of government expenditure in three time periods covered by the study reduced for central, Coast, Eastern, Nyanza, Rift valley and Western Provinces but increased for Nairobi and North Eastern Provinces across the period. The overall mean government allocation per school increased between 2000 and 2004 with the establishment of FPE and dropped significantly after the FPE programme stabilised in 2012 .

\section{Input and Output Target Change in Technical Efficiency}

Levels of technical efficiency change in outputs and inputs were explained by schools exhibiting decreasing returns to scale (drs), Increasing Returns to Scale (IRS) and/or constant returns to scale (crs) presented in Table 3.

Table 1: Number and percentage of schools sampled

\begin{tabular}{llllll}
\hline Year & 2000 & 2004 & 2012 & Mean & Standard deviation \\
\hline Coast & $22(12.6 \%)$ & $18(10.4 \%)$ & $15(8.3 \%)$ & 18.3 & 3.51 \\
Central & $35(20.1 \%)$ & $24(13.9 \%)$ & $23(12.7 \%)$ & 27.0 & 6.00 \\
Eastern & $24(13.8 \%)$ & $23(13.3 \%)$ & $22(12.2 \%)$ & 23.0 & 1.00 \\
Nairobi & $19(10.9 \%)$ & $19(10.98 \%)$ & $15(8.3 \%)$ & 17.7 & 2.30 \\
Rift Valley & $24(13.8 \%)$ & $28(16.2 \%)$ & $38(20.99 \%)$ & 30.0 & 7.20 \\
Nyanza & $20(11.5 \%)$ & $23(13.3 \%)$ & $34(18.8 \%)$ & 25.0 & 7.40 \\
Western & $15(8.62 \%)$ & $24(13.9 \%)$ & $22(12.2 \%)$ & 20.0 & 4.72 \\
North Eastern & $15(8.6 \%)$ & $14(8.1 \%)$ & $12(6.6 \%)$ & 13.7 & 1.53 \\
Total & 174 & 173 & 181 & 176.0 & 4.35
\end{tabular}

Source: Authors Computation Based on SACMEQ Survey data

Table 2: Mean government expenditure

\begin{tabular}{lllllll}
\hline & 2000 & & 2004 & & 2012 & \\
Province & Mean & Standard deviation & Mean & Standard deviation & Mean & Standard deviation \\
\hline Central & $1,030,890$ & $660,276.2$ & $769,811.8$ & $296,505.6$ & $480,274.6$ & $220,284.8$ \\
Coast & $939,129.5$ & $752,259.7$ & $737,702.0$ & $356,629.7$ & $703,215.3$ & $361,027.2$ \\
Eastern & $569,264.0$ & $287,237.9$ & $530,759.0$ & $256,185.5$ & $413,787.2$ & $217,930.1$ \\
Nairobi & $1,205,449$ & $364,168.5$ & $1,216,258.0$ & $398,010.6$ & $1,282,608$ & $552,954.5$ \\
North Eastern & $826,018.7$ & $478,641.5$ & $1,058,135.0$ & $643,337.2$ & $171,800.5$ & $32,021.6$ \\
Nyanza & $543,366.1$ & $339,848.0$ & $518,805.4$ & $405,103.6$ & $484,393.8$ & $254,402.5$ \\
Rift valley & $663,115.8$ & $264,743.3$ & $650,955.2$ & $273,526.7$ & $610,123.5$ & $337,802.0$ \\
Western & $867,895.6$ & $556,341.1$ & $7,080,391.0$ & $342,887.2$ & $723,979.5$ & $357,703.4$ \\
Total Mean & $5,614,238$ & & $1,2562,818$ & & $4,870,182$ &
\end{tabular}

Source: Authors Computation Based on SACMEQ Survey data 


\section{Determinants of (in) Efficiency in Technical Efficiency}

To estimate the determinants of efficiency, second stage analysis was carried out using Tobit model where the dependent variable included levels of inefficiency which were either 0 or $1\left(u_{i}=(1-\right.$ effieicny $)$ and results presented in Annex, Table 3.

\section{Technological Change in Technical Efficiency}

The Solow model on productivity analysis $Y=$ $A K^{\alpha} L^{\beta}$ was applied to account for effects in total output if inputs were used to determine a measure of technological dynamism as presented as overall efficiency change, the technological efficiency change, scale efficiency change, pure technological efficiency and aggregated TFP in Table 4.

Table 3: Technical efficiency change, output and input change levels

\begin{tabular}{|c|c|c|c|c|c|c|c|c|c|c|c|c|}
\hline \multicolumn{6}{|c|}{ Efficiency levels at province levels } & \multicolumn{2}{|l|}{ Output change } & \multicolumn{5}{|c|}{ Input change } \\
\hline Province & Year & CRSTE & VRSTE & SCALE & $\begin{array}{l}\text { Levels } \\
\text { of scale }\end{array}$ & $\begin{array}{l}\text { Arithmetic } \\
\text { average } \\
\text { score change }\end{array}$ & $\begin{array}{l}\text { Reading } \\
\text { average } \\
\text { score change }\end{array}$ & $\begin{array}{l}\text { Total } \\
\text { enrolment } \\
\text { change }\end{array}$ & $\begin{array}{l}\text { Government } \\
\text { expenditure } \\
\text { change }\end{array}$ & $\begin{array}{l}\text { Toilets } \\
\text { change }\end{array}$ & $\begin{array}{l}\text { Total } \\
\text { classes } \\
\text { change }\end{array}$ & $\begin{array}{l}\text { Total } \\
\text { teachers } \\
\text { change }\end{array}$ \\
\hline \multirow[t]{3}{*}{ Central } & 2000 & 0.790 & 1.000 & 0.790 & drs & - & - & & - & - & - & - \\
\hline & 2004 & 0.746 & 0.981 & 0.760 & drs & 11.102 & 36.797 & -0.892 & - & -6.518 & -1.083 & -0.787 \\
\hline & 2012 & 0.900 & 1.000 & 0.900 & drs & - & - & - & - & - & - & - \\
\hline \multirow[t]{3}{*}{ Coast } & 2000 & 1.000 & 1.000 & 1.000 & - & - & - & - & - & - & - & - \\
\hline & 2004 & 0.828 & 0.978 & 0.846 & drs & 16.500 & 12.800 & -75.5 & $-97,273.3$ & - & -2.1 & -0.7 \\
\hline & 2012 & 1.000 & 1.000 & 1.000 & - & - & - & - & - & - & - & - \\
\hline \multirow[t]{3}{*}{ Eastern } & 2000 & 0.793 & 0.997 & 0.795 & drs & 1.727 & 1.742 & -5.46 & - & -0.375 & - & -1.932 \\
\hline & 2004 & 1.000 & 1.000 & 1.000 & - & - & - & - & - & - & - & - \\
\hline & 2012 & 1.000 & 1.000 & 1.000 & - & - & - & - & - & - & - & - \\
\hline \multirow[t]{3}{*}{ North Eastern } & 2000 & 0.947 & 0.988 & 0.958 & drs & 6.167 & 8.667 & -142 & $-42,978$ & - & - & -1.167 \\
\hline & 2004 & 0.843 & 0.973 & 0.866 & drs & 15.200 & 21.200 & -426 & $-548,284.8$ & - & -5.0 & -6.2 \\
\hline & 2012 & 0.676 & 1.000 & 0.676 & drs & - & - & - & - & - & - & - \\
\hline \multirow[t]{3}{*}{ Nairobi } & 2000 & 0.627 & 0.100 & 0.627 & drs & - & - & - & - & - & - & - \\
\hline & 2004 & 0.629 & 1.000 & 0.629 & drs & - & - & - & - & - & - & - \\
\hline & 2012 & 0.488 & 1.000 & 0.488 & drs & - & - & - & - & - & - & - \\
\hline \multirow[t]{3}{*}{ Nyanza } & 2000 & 1.000 & 1.000 & 1.000 & - & - & - & - & - & - & - & - \\
\hline & 2004 & 1.000 & 1.000 & 1.000 & - & - & - & - & - & - & - & - \\
\hline & 2012 & 1.000 & 1.000 & 1.000 & - & - & - & - & - & - & - & - \\
\hline \multirow[t]{3}{*}{ Rift valley } & 2000 & 1.000 & 1.000 & 1.000 & - & - & - & - & - & - & - & - \\
\hline & 2004 & 0.877 & 0.946 & 0.927 & drs & 31.778 & 50.444 & -45.22 & $-57,659.33$ & -0.778 & - & -0.556 \\
\hline & 2012 & 0.793 & 0.936 & 0.848 & drs & 36.794 & 48.458 & -90.315 & $-83,609.27$ & - & - & - \\
\hline \multirow[t]{3}{*}{ Western } & 2000 & 0.884 & 0.940 & 0.940 & drs & 33.333 & 37.834 & -10.5 & $-139,064$ & - & - & -0.333 \\
\hline & 2004 & 0.892 & 0.955 & 0.935 & drs & 25.800 & 28.800 & -96 & $-123,474$ & - & 1 & -0.8 \\
\hline & 2012 & 0.693 & 0.895 & 0.774 & drs & 60.224 & 63.656 & -132.525 & $-123,384.7$ & - & -1.888 & - \\
\hline
\end{tabular}

*** $\mathrm{p}<0.01, * * \mathrm{p}<0.05, * \mathrm{p}<0.1$; Standard errors in parentheses Source: Authors Computation Based on SACMEQ Survey data

Table 4: Technological efficiency analysis for 8 provinces (2000, 2004 and 2012)

\begin{tabular}{|c|c|c|c|c|c|c|}
\hline Province & Year & $\begin{array}{l}\text { Efficiency } \\
\text { change }\end{array}$ & $\begin{array}{l}\text { Technical } \\
\text { efficiency change }\end{array}$ & $\begin{array}{l}\text { scale efficiency } \\
\text { change }\end{array}$ & $\begin{array}{l}\text { Pure technological } \\
\text { efficiency }\end{array}$ & $\begin{array}{l}\text { Total factor } \\
\text { productivity }\end{array}$ \\
\hline \multirow[t]{3}{*}{ North Eastern } & 2004 & 0.814 & 0.789 & 1.034 & 0.7880 & 0.643 \\
\hline & 2012 & 1.030 & 0.897 & 0.942 & 1.9420 & 0.925 \\
\hline & Mean & 0.916 & 0.842 & 0.987 & 0.9280 & 0.771 \\
\hline \multirow[t]{3}{*}{ Central } & 2004 & 0.935 & 0.985 & 1.000 & 0.9350 & 0.921 \\
\hline & 2012 & 1.256 & $* * *$ & 1.019 & 1.2320 & $* * *$ \\
\hline & Mean & 1.084 & *** & 1.010 & 1.0740 & $* * *$ \\
\hline \multirow[t]{3}{*}{ Coast } & 2004 & 0.908 & 1.147 & 1.009 & 0.9000 & 1.042 \\
\hline & 2012 & 0.926 & 1.014 & 0.923 & 1.0030 & 0.939 \\
\hline & Mean & 0.917 & 1.079 & 0.923 & 0.9500 & 0.989 \\
\hline \multirow[t]{3}{*}{ Eastern } & 2004 & 0.914 & 1.22 & 0.974 & 0.9390 & 1.115 \\
\hline & 2012 & 1.096 & 1.026 & 1.019 & 1.0750 & 1.125 \\
\hline & Mean & 1.001 & 1.119 & 0.996 & 1.0050 & 1.12 \\
\hline \multirow[t]{3}{*}{ Nairobi } & 2004 & 1.050 & 227.837 & 1.005 & 1.0450 & 239.211 \\
\hline & 2012 & 0.716 & 1.506 & 0.937 & 0.7640 & 1.078 \\
\hline & Mean & 0.867 & 18.521 & 0.970 & 0.8930 & 16.055 \\
\hline \multirow[t]{3}{*}{ Nyanza } & 2004 & 0.849 & 1.163 & 0.957 & 0.0888 & 0.988 \\
\hline & 2012 & 1.211 & 0.855 & 1.061 & 1.1420 & 1.035 \\
\hline & Mean & 1.014 & 0.997 & 1.007 & 1.0070 & 1.011 \\
\hline \multirow[t]{3}{*}{ Rift valley } & 2004 & 0.795 & 0 & 0.939 & 0.8470 & 0 \\
\hline & 2012 & 1.127 & 0.853 & 1.058 & 1.0650 & 0.961 \\
\hline & Mean & 0.946 & 0 & 0.997 & 0.9490 & 0 \\
\hline \multirow[t]{3}{*}{ Western } & 2004 & 1.251 & 0.902 & 1.060 & 1.1800 & 1.128 \\
\hline & 2012 & 0.984 & 0.48 & 0.989 & 0.9960 & 0.736 \\
\hline & Mean & 1.109 & 0.821 & 1.024 & 1.0840 & 0.911 \\
\hline
\end{tabular}

Source: Authors Computation 


\section{Conclusions and Policy Recommendations}

\section{Conclusion}

Efficiency analysis shows that there exit a process change from inputs to outputs that had greater impact to VRSTE compared to CRSTE in the three year period. Efficiency results both at VRSTE and CRSTE dropped across the three time period but with varied levels in different provinces and these depended on input and output levels as well as on levels of FPE stabilization. These results conformed to Charnes et al. (1978) and Liu and Mills (2007) who identified efficiency to depend on levels of inputs and outputs in different time periods.

Thus, for a school to remain technically efficient, it should have an input and output target. The inputs and output changes in the analysis provided either the number of inputs that should be reduced or added to make schools in various provinces efficient as explained by various scale efficiencies. Referring to the Solow model productivity analysis $Y=A K^{\alpha} L^{\beta}$ which accounted for effects in total output when inputs were controlled for to determine a measure of technological dynamism; the trends in efficiency change were evident within technical efficiency change, scale efficiency change, pure technical efficiency and total factor productivity that declined between 2000 and 2004 but improved between 2004 and 2012 (Table 2). From a Tobit model, second stage regressions results were criticised by their likelihood for biasness on small samples with a proposal to apply alternative and inference procedures (Afonso and Anbyn, 2006).

Schools characteristics analyzed against inefficiency scores showed that class-pupil ratio, pupil -toilet ratio, pupil-teacher ratios, school distance from small town, dispensary, bookshop and secondary school as well as class types contributed negatively to efficiency. These results also showed high statistical significance at both 99, 95 and $90 \%$ levels respectively in 2012 when it was assumed that the FPE programme had stabilized.

\section{Policy Implications}

Borrowing from the Ugandan case where Muvawala and Hisali (2012) compared the efficiency of government and primary schools, there was evidence that as outlined by Grosskopf et al. (1997), private schools were more efficiently operated. If the school operational efficiency were adopted in most provinces, these could lead to reduced expenditure by up to $30 \%$ and still achieve the same outcomes.

From the Ugandan case, efficiency interventions introduced in the context of current resource allocations to primary education would result in a mere $1 \%$ improvement in learning outcomes. However, in the Kenyan case, the levels of efficiency would change between $12.5-15.1 \%$ of school performance and this would improve learning outcomes greatly. In order to adopt findings of this study, the government should set up a taskforce to establish the unit cost of education from the basic school levels to university level. The taskforce should also provide the unit cost of teacher capacity development as well as the efficiency models to be adopted in all school types disaggregated by school location. This model can be analyzed from the Computable General Equilibrium (CGE) model that shows the macro-economic impact of government investment in various sectors.

\section{Acknowledgment}

This study makes ackonowdegment to the Southern and Eastern Africa Consortium for Monitoring Educational Quality (SACMEQ) and the United Nations Education, Scientific and Cultural Organization (UNESCO) for allowing the use of the data collected from their work in this study. The SACMEQ based data formed a bulk of the data used in the study. Other data were from the Kenya National Examinations Council (KNEC) and the Kenya National Bureau of Statistics (KNBS).

\section{Author's Contributions}

The authors to this study have made great contribution to efficiecny analysis in the education sector. This is well notable because most of the efficiency studies have been undertaken in the health, manufacturing and banking sector. The study sets precedence for further studies in determining efficiencies in education environment. The main author developed the publication with the supporting authors contributing in model alignment and revision of the paper.

\section{Ethics}

This paper has been undertaken with highest level of indepedence and originality. All the iformation provided in the study is the responsbility of the author.

\section{References}

Abagi, O. and G. Odipo, 1997. Efficiency of primary education in Kenya: Situational analysis and implication for educational reforms. IPAR, Discussion Paper, DP.1004/97

Afonso, A. and M. Aubyn, 2006. Cross-country efficiency of secondary education provision: A semi-parametric analysis with non-discretionary inputs. Economic Modell., 23: 476-491. DOI: 10.1016/j.econmod.2006.02.003

Aghion, P. and P. Howitt, 1988. Growth and cycles through creative destruction. University of Western Ontario. 
Aigner, D.J. and S.F. Chu, 1968. On Estimating the Industry Production Function. Am. Economic Rev., 58: 826-839.

Alesina, A. and D. Dani Rodrik, 1994. Distributive politics and economic growth. Quarterly J. Econom., 108: 465-90. DOI: $10.2307 / 2118470$

Benhabib, J. and M.M. Spiegel, 1994. The role of human capital in economic development evidence from aggregate cross-country data. J. Monetary Econom., 34: 143-173. DOI: 10.1016/0304-3932(94)90047-7

Bedi, A., P. Kimalu, D. Kulundu and N. Nafula, 2002. The decline in primary school enrolment in Kenya. KIPPRA Discussion Paper No. 14, KIPPRA, Nairobi.

Bold, T., M. Kimenyi, G. Mwabu and J. Sandefur, 2011. Why did abolishing fees not increase public school enrolment in Kenya. Centre for Global Development, Working paper, 271.

Bowlin, W., 1996. Measuring performance; an introduction to Data Envelopment Analysis (DEA). Department of Accounting, University of Northern IOWA.

Bowers, A. and A. Urick, 2011. Does high school facility quality affect student achievement? A twolevel hierarchical linear model. J. Educ. Finance, 437: 72-94.

Breusch, T., G.E. Mizon and P. Schmidt, 1989. Efficient estimation using panel data. Econometrica, 57: 695-700. DOI: $10.2307 / 1911060$

Burgess, R., 1998. 'Land, welfare and efficiency in rural China', London School of Economics

Cameron, C. and P. Trivedi, 2010. Micro Econometrics Using Stata, 2nd Edn., Stata Press, ISBN-10: 1597180734, pp: 706.

Charnes, A., W.W. Cooper and E. Rhodes, 1978. Measuring the efficiency of decision making units. Eur. J. Operat. Res., 11: 429-444. DOI: 10.1016/0377-2217(78)90138-8

Charnes, A. and W. Cooper, 1985. Preface to topics in data envelopment analysis. Ann. Oper. Res., 2: 59-94. DOI: $10.1007 / \mathrm{BF} 01874733$

Coelli, T.J., 1996. A guide to DEAP version, 2.1. A data envelopment analysis, computer program. CEPA Working Paper 1996/98, Department of Econometrics, University of New England.

Cohen, J. and P. Dupas, 2010. Free distribution or cost sharing? Evidence from randomised malaria prevention experiment. Quarterly J. Econom., 125: 1-25. DOI: 10.1162/qjec.2010.125.1.1

Debreu, G., 1951. The coefficient of resource utilization. Econometrica, 19: 273-293. DOI: 10.2307/1906814

Farrell, M.J., 1957. The measurement of productive efficiency. J. Royal Stat. Society, 120: 253-290.

Fishlow, 1995. Inequality, poverty and growth: Where do we stand? Proceedings of the Annual Bank Conference on Development Economics, (CDE' 95), Washington, D.C.
Grosskopf, S., J. Kathy, L. Taylor and W. Weber, 1997. Budget constrained frontier measures of fiscal equality and efficiency in schooling. Rev. Econom. Stat., 79: 116-124. DOI: 10.1162/003465397556458

Hanushek, E. and L. Woessmann, 2008. The role of cognitive skills in economic development. J. Economic Literature, 46: 607-668. DOI: $10.1257 /$ jel.46.3.607

Kanina, J.W., 2013. Technical efficiency and total factors productivity of primary schools in Kenya, University of Nairobi.

Kimalu, P.K., N. Nafula, D.K. Kulundu, A. Bedi and G. Mwabu et al., 2001. Education indicators in Kenya. KIPPRA Working Paper, Series WP/04/2001, KIPPRA, Nairobi.

Kirigia, J., L.G. Sambo and H. Scheal, 2000. Technical efficiecny in Kwazulu-Natal province of South Africa. East African Med. J.

Koopmans, T., 1951. "Analysis of Production as an Efficient Combination of Activities. In: Activity Analysis of Production and Allocation, Koopmans, T.C. (Ed.), Yale University Press, New York, pp: 33-97.

Koopmans, R., 2013. Multiculturalism and immigration. A contested field in cross-national comparison. Annual Rev. Sociol., 39: 147-169.

DOI: 10.1146/annurev-soc-071312- 145630.

Kwabena, G. and E. Appiah, 2004. Technical efficiency in Ghanaian secondary schools. University of South Florida.

Lee, V., T. Zuze and K. Ross, 2005. School effectiveness in 14 sub-Saharan African countries links with $6^{\text {th }}$ grades reading achievement. Stud. Educ. Evaluat., 31: 207-246. DOI: 10.1016/j.stueduc.2005.05.011

Liu, X. and A. Mills, 2007. Supplier Induced Demand and Unnecessary Care. In: Public Ends and Private Means: Strategic Purchasing of Health Services, Preker, A., X. Liu, E.V. Velenyi and E. Baris, (Ed.), World Bank, Washington D.C.

Lovell, C.A.K., 1993. Production Frontiers and Productive Efficiency. In: The Measurement of Productive Efficiency: Techniques and Applications, Fried, H.O. and S.S. Schmidt (Eds.), Oxford, UK, pp: 3-67.

Lovell, A.K. and P. Schmidt, 1977. Formulation and estimation of stochastic frontier production function models. J. Econometr., 6: 21-37. DOI: 10.1016/0304-4076(77)90052-5

Lucas, R., 1988. On the mechanics of economic development. J. Monetary Econom., 22: 3-42. DOI: 10.1016/0304-3932(88)90168-7

Mankiw, G., D. Romer and D. Weil, 1992. A contribution to the empirics of economic growth. Quarterly J. Econom., 107: 407-437. 
Mazar, N., A. Ariely and R. Shampanier, 2007. Zero value as a special price. The true value of free products. Market. Sci., 26: 742-757.

Mincer, J., 1974. Schooling, experience and earnings, national bureau of economic research. Distributed by Columbia University Press, New York.

Mizala, A.P. and U. Miguel, 2007. Parental Choice and School Markets: The Impact of Information Approximating School Effectiveness. Unpublished manuscript, Columbia University

Mizala, A. and P. Rumaguera, 2000. School performance and choice: The children experience. J. Human Resources, 35: 392-417. DOI: 10.2307/146331

Muyanga, M., J. Olwande, E. Mueni and S. Wambugu, 2010. Free primary education in Kenya: An impact evaluation using propensity score methods. PMMA Working Paper 2010-08.

Muvawala, J. and E. Hisali, 2012. Technical efficiency in Uganda's primary education system: Panel data evidence. African Stat. J., 15: 69-84.

Nelson, R. and E. Phelps, 1966. Investment in humans, technological diffusion and economic growth. Am. Economic Rev., 56: 69-75.

Nyamoita, E., 2013. Benefit incidence and efficiency of public spending on education and training in Kenya. University of Nairobi.
Odusola, A.F., 1998. Human capital investment and the empirics of economic growth in Nigeria. Proceedings of the Rekindling Investment for Economic Development in Nigeria Selected Papers for NES Annual Conferences, (AC' 98), Nigerian Economic Society, Ibadan, pp: 257-272.

Persson, T. and G. Tabellini, 1994. Is inequality harmful for growth? Am. Economic Rev., 84: 600-621.

Pitt, M.M. and L.F. Lee, 1981. Measurement and sources of technical inefficiency in the Indonesian weaving industry. J. Dev. Econom., 9: 43-64. DOI: $10.1016 / 0304-3878(81) 90004-3$

Republic of Kenya, 2005. A policy framework for education, training and research. MOEST, Sessional Paper No. 1, Republic of Kenya.

Republic of Kenya, 2007. Economic surveys (1998-2007).

Romer, P., 1990. Capital, labor and productivity. Brookings Papers on Econ. Activity.

Salvanes, K.G. and S. Tjøtta, 1998. A test for natural monopoly with application to Norwegian electricity distribution. Rev. Indust. Organiz., 13: 669-685. DOI: $10.1023 / \mathrm{A}: 1007708912329$

Woodridge, J.M., 2002. Econometric Analysis of Cross Section and Panel Data. 2nd Edn., MIT Press, Cambridge, ISBN-10: 0262232197, pp: 752.

Worthington, A., 2001. An empirical survey of frontier efficiency measurement techniques in education. Educ. Econom., 9: 245-268.

DOI: $10.1080 / 09645290110086126$ 